Int. J. Electrochem. Sci., 12 (2017) $2836-2851$

\title{
Comparing Natural and Artificially Designed Bacterial Consortia as Biosensing Elements for Rapid Non- Specific Detection of Organic Pollutant through Microbial Fuel Cell
}

\author{
Maira Anam, Sameen Yousaf, Iqra Sharafat, Zargona Zafar, Kamran Ayaz, Naeem Ali ${ }^{*}$ \\ Department of Microbiology, Quaid-i-Azam University, Islamabad, Pakistan \\ *E-mail: naeemali2611@gmail.com
}

doi: $10.20964 / 2017.04 .49$

Received: 8 November 2016 / Accepted: 17 February 2017 / Published: 12 March 2017

The standard 5-days biochemical oxygen demand (BOD) method used for determination of biologically oxidizable organic material in wastewater considered to be laborious, time consuming and costly. Mediator-less microbial fuel cell (MFC) based biosensor offers an efficient alternative approach for real time monitoring of biodegradable organic matter in wastewater. Here we constructed an $\mathrm{H}$ shaped MFC biosensor for comparing the efficiency of a complex natural (activated sludge) and artificially designed bacterial (Pseudomonas aeruginosa, Staphylococcus aureus and Bacillus circulans) consortia as biological sensing elements for BOD measurements. Initially, the MFC biosensor was optimized and calibrated at $\mathrm{pH} 7$ and temperature $37^{\circ} \mathrm{C}$ using $100 \mathrm{mM}$ phosphate buffer with $100 \mathrm{mM} \mathrm{NaCl}$ solution as catholyte at $10 \mathrm{k} \Omega$ external resistance. Maximum power density of 14.2 $\mathrm{mW} / \mathrm{cm}^{2}$ was generated by MFC-I with sludge consortium and it was 5 folds higher than MFC-II with artificial consortium. Standard glucose and glutamic acid (GGA) solutions were used for establishing the calibration curves between different BOD concentrations $(50-250 \mathrm{mg} / \mathrm{L})$ and voltage $(\mathrm{mV})$ outputs in MFC. The regression equations for MFC-I and MFC-II biosensors were recorded as $\mathrm{y}_{1}=0.7834 \mathrm{x}-$ 11.638 and $\mathrm{y}_{2}=0.1667 \mathrm{x}+0.8476$ respectively. Linear regression analysis revealed that $1 \mathrm{unit}(\mathrm{mg} / \mathrm{L})$ increase in organic load caused a voltage increase of $0.78 \mathrm{mV}$ and $0.16 \mathrm{mV}$ in the MFCs (I and II) reactors respectively. The relative performance in terms of stability (55-60 days) and reproducibility (within $\pm 15.4 \%$ ) of MFC-I BOD biosensor was almost double than MFC-II. The varying low concentrations of different electron acceptors (phosphate, nitrate and nitrite) in anodic compartments did not affect the performance of MFC biosensors.

Keywords: MFC biosensor, Biochemical oxygen demand (BOD), Natural consortia, Artificial consortia, Pyrosequencing

FULL TEXT 
(C) 2017 The Authors. Published by ESG (www.electrochemsci.org). This article is an open access article distributed under the terms and conditions of the Creative Commons Attribution license (http://creativecommons.org/licenses/by/4.0/). 